\title{
CADERno DE POESIA III
}

Betina dos Santos Ruiz ${ }^{1}$

1

Uma oração e serei menos.

Com simpatia sei que serei mais.

Guias, amuletos, escapulários... vários.

Uma vela - cada um dos sete raios -,

imagens de santo, a boneca vermelha de Orixá.

O Divino Espírito Santo, asas abertas.

A estrela do mar.

Muito mais mar!

Búzios,

odores marinhos vindos do incenso,

a lembrança da água:

som,

brilho.

movimento,

Correndo para mim apenas

a me abençoar.

2

É dia das crianças em quantas certas casas:

Isabela está triste, mas a fala tem sua ternura.

Miguel ouve a música e balança o corpo todo.

João emite uns sons que eu talvez compreenda.

Só não achei criança a quem dar o doce da minha promessa.

Faz muito frio em São Paulo. Faz muito frio lá fora.

As crianças de rua onde estão?

Haverá rua só para elas?

Para elas?

Nessas ruas não andei. Nelas não estive, ainda.

${ }^{1}$ Doutoranda em Estudos Comparados de Literaturas de Língua Portuguesa. FFLCHUSP. Pesquisa: Heroínas culturais, um estudo sobre Sóror Mariana Alcoforado e Sor Juana Inés de la Cruz. E-mail: betinasr@yahoo.com.br 
3

Às vezes, a gente tem tanta energia

E sai um feto mal feito.

Às vezes, a gente tem tanta energia

e sai um traço sem jeito.

Às vezes, tem tanta energia,

a luz risca o ar.

4

Doce, doce,

dobro e desço,

desvio,

deslizo,

derreto o gelo.

Descalça ou de saltos altos.

Divago com o corpo.

Devagar, devagar,

distraio e disperso,

despisto,

desmascaro,

desato os nós.

Dou o tom porque descortino.

Dispo a alma: danço.

Distraída, distraída,

desloco o eixo, distribuo o peso,

de leve toco o chão,

de novo me dobro,

divirto-me com o ritmo.

Demonstro a minha alegria.

Depois perco o compasso.

Desfeita deixo a música.

Depressa deito na cama.

Desativo a máquina.

Descanso o peito e durmo um pouco.

De lado ou de bruços.

De costas para o movimento.

Devolvo tudo à calmaria. 


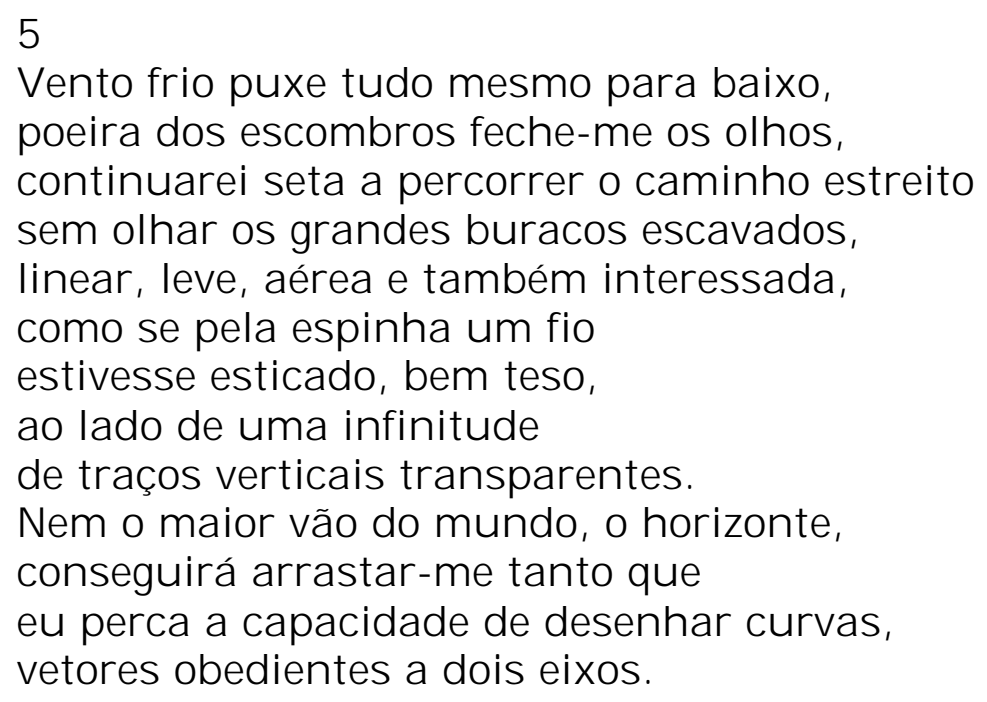

6

A árvore mais alta desta rua tem um deus.

Ganhou dele folhas pequenas para nos dias de vento ser chocalho.

A esta distância, o desenho da copa é como o intervalo entre duas mãos em concha.

E se oscila!

Faz lembrar quão bom é ter mãos humanas, para produzir o gesto e gerar o som.

O farfalhar ao ouvido atento suplanta toda preocupação, que não é fruto desta árvore...

Vista assim de frente, o meu melhor exemplar de árvore é evocação da vida,

é moto-contínuo, que só as formas de amor semeiam.

\section{7}

\section{Casamento moderno}

Se a liberdade é mesmo

azul,

então devo pintar estas paredes

de mar.

Aí te convido a ficar

nesta casa

comigo.

A dividir

esta casa

comigo.

E a sós

entre nossas quatro paredes,

compartilho o desejo

de sermos

um

e o infinito. 
8

Difícil descoberta...

que não é o mesmo que me devolver a um estado de pureza.

Ainda não.

É antes a essencial percepção:

estou diante do espelho,

desistências pesam sobre aquilo que me tornei.

O desânimo com a flauta

(e teria antes desta, outra linguagem).

O descaso para com a ginástica do corpo

(e teria então mais fiel aliado).

À deriva com a percussão

(ficou-me, ao menos, uma cadência preguiçosa).

A despeito do francês, sobrevivi

(o verso caberia também a Mariana Alcoforado).

E o muito mais não aprendido que me agüente assim,

observe-me agora,

intrometa-se em meus sonhos e

nas visões fáceis que tenho quando ando desperta e feliz

9

Moço corado do cabelo cortado a militar,

eu te vi no passeio a rir com os amigos,

guardei comigo seu frêmito benfazejo.

Menina nascida doente faz vinte anos,

se não te avistara ainda de dia,

a subir da rua para a praça com a ajuda da mãe,

percebi sua presença luz que pontilha a noite de festa.

Velhos compadres desta e doutra freguesia,

o cortejo composto pela vossa gente

estava bonito enquanto o acompanhei à distância.

Casais jovens vestidos para o tédio,

a vida é mesmo assim, sucessão de comemorações

a que só damos sentido

se acendermos nossa lâmpada mágica.

Bebês, cães vadios aconchegados pelos que invadiram o território

e também os outros muito assustados com o barulho dos fogos,

estamos todos reunidos em junho.

Quem nos orienta até este sítio

e nos sustém neste intervalo agradável?

Por quanto tempo de relógio esta ciranda? 
10

A vida é uma coisa ou duas?

Ou trama complexa demais,

teia que se recompõe,

tecido de muitas estampas,

unidade:

a minha vida trançada à sua, seja você quem for.

Ou retas que por acaso se cruzam,

planos muito próximos,

pontos de profundidade incomensurável,

porém ímpares neste universo:

a minha e além mais outra.

Não preferir esta àquela possibilidade.

Apenas perguntar como isto funciona.

Afinal, o vento sopra por isto!

Animais obedecem aos delicados sinais.

Cada arbusto, toda a floresta sabe de cor a canção.

Nós, nem o solfejo... 